\title{
GENOTYPIC IDENTIFICATION OF Cryptosporidium SPP. ISOLATED FROM HIV-INFECTED PATIENTS AND IMMUNOCOMPETENT CHILDREN OF SÃO PAULO, BRAZIL
}

\author{
Ana Julia Urias dos Santos ARAÚJO(1,2), Herminia Yohko KANAMURA(1,2), Marcos Eduardo de ALMEIDA(1), Aparecida Helena de Souza GOMES(3),
} Thais Helena Lemos PINTO(4) \& Alexandre Januário DA SILVA(5)

\begin{abstract}
SUMMARY
Cryptosporidium isolates identified in fourteen stool samples, collected from five HIV-infected patients and nine immunocompetent children, living in the Sate of São Paulo, Brazil, were submitted to a molecular analysis using a nested PCR followed of restriction fragment length polymorphism (RFLP), for genetic characterization. The analysis was based on digestion with RsaI restriction enzyme of a DNA fragment amplified from the Cryptosporidium oocyst wall protein (COWP) gene. Based on this analysis, four samples were identified as Cryptosporidium parvum, eight as Cryptosporidium hominis and two presented a profile that corresponded to Cryptosporidium meleagridis when compared to the standards used in the analysis. The use of molecular methods can be helpful to identify source of infections and risk factors related to Cryptosporidium infection in our communities.
\end{abstract}

KEYWORDS: Cryptosporidiosis; PCR; Genotyping; Cryptosporidium parvum; Cryptosporidium hominis; Cryptosporidium meleagridis; Brazil.

\section{INTRODUCTION}

Nearly 100 years after description of the first Cryptosporidium species, in mice by Tyzzer, it is known that Cryptosporidium spp. can occur in distinct classes of vertebrates, such as fishes, reptiles, amphibians, birds and mammals $12,20,27,28$.

In humans, infection by Cryptosporidium sp. was first registered in 1976, and Cryptosporidium parvum (previously known as cattle genotype or genotype 2) and Cryptosporidium hominis (previously known as $C$. parvum - human genotype or genotype 1) have been recorded as the two species most frequent cause of human cryptosporidiosis, either associated with sporadic cases of infections or outbreaks, some of them being very large as the one that occurred in Milwaukee WI, USA, which affected approximately 400,000 persons ${ }^{12,17}$. To date, all the cryptosporidiosis outbreaks occurring worldwide have been caused by C. hominis and C. parvum, with several being associated with consumption of drinking water or exposure to recreational water contaminated with Cryptosporidium oocysts of zoonotic and anthroponotic origins ${ }^{15,27,30}$. Due to the size and frequency of these outbreaks, cryptosporidiosis became a serious public health issue worldwide and prompted reevaluation of the microbiological standards for drinking water by health authorities in developed and developing countries. In countries like Brazil, it is mandatory that potable water be also free of Cryptosporidium sp. and Giardia sp. ${ }^{3}$.

Although all outbreaks studied to date have been associated with the two species of Cryptosporidium listed above, it is also known that at least some zoonotic species, such as Cryptosporidium canis, Cryptosporidium felis, and Cryptosporidium meleagridis, can indeed infect both immunocompromised and immunocompetent persons $s^{4,14,18,21,22,24}$.

In different regions of Brazil, including São Paulo, studies involving patients with compromised immune systems either HIV-positive or not, and children, with or without diarrhea, have shown different rates for presence of Cryptosporidium spp. in their stools s, $7,8,15,19,25^{\text {. }}$ Serological surveys conducted in Brazil showed the presence of antiCryptosporidium antibodies in a large number of children living in slums of the northeastern region of Fortaleza, state of Ceara ${ }^{1}$, and also in individuals with no intestinal symptoms living in the state of São Paulo. In this last study the frequencies for anti-Cryptosporidium antibodies varied from $10 \%$ to $80 \%$, according to the age group ${ }^{9}$. Environmental contamination with Cryptosporidium was also reported in rivers and other public water sources ${ }^{11,13}$. Despite the great number of reports about occurrence of Cryptosporidium infection in Brazil, only few studies addressed the molecular characterization of the isolates found in the studied clinical specimens. In one of the studies carried out in the northeast region, two isolates were identified as C. parvum, one as $C$. hominis, but the authors were not able to genetically characterized one of the isolates ${ }^{2}$. Other study identified seven Brazilian children infected with $C$. hominis ${ }^{14}$ and another revealed the presence of a single genotype of $C$. hominis based on analysis of three genes in 29 samples from a diarrhea outbreak investigated in a day care in São Paulo, $\mathrm{SP}^{15}$. 


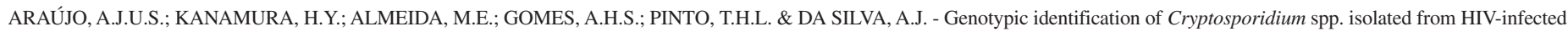
patients and immunocompetent children of São Paulo, Brazil. Rev. Inst. Med. trop. S. Paulo, 50(3): 139-143, 2008.

In the present study, a nested PCR followed by RFLP, of a fragment of the Cryptosporidium oocyst wall protein (COWP) gene, was used to identify the species of Cryptosporidium isolates from HIV-infected patients and immunocompetent children living in the Sate of São Paulo, Brazil.

\section{MATERIAL AND METHODS}

Cryptosporidium isolates. A total of 14 stool samples, positive for Cryptosporidium sp. by microscopic examination of stools, were obtained from adults and children, with or without diarrhea, living in three cities of the State of Sao Paulo, Brazil. Five samples (SO32, SO49, SO507, SO623 and SO689) were obtained from HIV-infected patients submitted to diagnostic testing at the Public Health Laboratory of Sorocaba city; five samples (SP06, SP07, SP12, SP17 and SP31) were obtained from children living in a slum located in the city of São Paulo and submitted for testing by the Parasitology Laboratory of the Albert Einstein Hospital; and four samples (TT01, TT03, TT06 and TT07) were selected during an active laboratory survey focusing on identification of cases of cryptosporidiosis in day care center from the city of Taubate, São Paulo State. The aspect of the children's stool samples varied from formed $(n=6)$ to loose-diarrheic $(n=3)$ and they were included in the study after identification of Cryptosporidium oocysts by Kinyoun staining method or detection of Cryptosporidium antigens by ELISA test on micro plate (ProSpecT - Alexon Inc.). The study protocol was approved by the Research Ethical Committee of the University of Taubate.

DNA extraction. DNA was extracted from stool samples using the FastDNA ${ }^{\circledR}$ method (MP Biomedicals, Solon, OH), as previously described $^{10}$ with the exception that the samples were disrupted using vortex mixer, instead of the FP120 FastPrep cell disrupter. For disruption, samples were agitated by vortexing during one minute three consecutive times. The extracted DNA was further purified with the QIAquick PCR purification kit (Qiagen, Inc., Santa Clarita, CA), according to manufacturer's instructions, for complete removing of the PCR inhibitors ${ }^{10}$, and then stored at $-20{ }^{\circ} \mathrm{C}$.

Amplification of fragments from the COWP gene. Nested-PCR was carried out using the protocol described by PEDRAZA-DIAZ et $a l .{ }^{23}$ : in the first step amplification, primers BCOWPF (ACC GCT TCT CAA CAA CCA TCT TGT CCT C) and BCOWPR (CGC ACC TGT TCC CAC TCA ATG TAA ACC C) were used to produce a fragment of 769-bp; in the secondary PCR, primers Cry 15 (GTA GAT AAT GGA AGA GAT TGT G) and Cry9 (GGA CTG AAA TAC AGG CAT TAT CTT G), described by SPANO et al. ${ }^{26}$, were used to amplify a DNA fragment of 553-bp. PCR reactions were performed in a total volume of $25 \mu \mathrm{L}$ containing $2.5 \mu \mathrm{L}$ of the DNA template in $1 \times$ PCR buffer, 1.5 $\mathrm{mM} \mathrm{MgCl}, 0.25 \mathrm{mM}$ of each dNTP (Amersham Bioscences), 10 pmoles of each primer, and 1.25 units of Taq DNA polymerase (Invitrogen, Brazil). Cycling conditions used were: initial denaturation cycle of $94^{\circ} \mathrm{C}$ for five minutes, followed by 30 cycles of $65^{\circ} \mathrm{C}$ for one minute, $72{ }^{\circ} \mathrm{C}$ for one minute and $94{ }^{\circ} \mathrm{C}$ for one minute; and a final extension at $72{ }^{\circ} \mathrm{C}$ for 10 minutes, which were carried out in a Mastercycle Gradient (Eppendorf, Hamburg, Germany). $2.5 \mu \mathrm{L}$ of the products of the primary PCR were amplified with Cry 15/Cry9 primers using the same volumes, concentrations of reagents and themocycler listed above. Cycling conditions for the nested PCR were: initial denaturation of $94{ }^{\circ} \mathrm{C}$ for five minutes, followed by 30 cycles of $55^{\circ} \mathrm{C}$ for 30 seconds, $72{ }^{\circ} \mathrm{C}$ for 50 seconds and $94^{\circ} \mathrm{C}$ for 50 seconds, and a final extension at $72{ }^{\circ} \mathrm{C}$ for 10 minutes. The PCR products were analyzed by electrophoresis on $1.5 \%$ agarose gel, stained with ethidium bromide, visualized on an ultraviolet transilluminator, and then digitalized (Digital Kodak Science 1D ${ }^{\mathrm{TM}}$ ).

RFLP analysis. An aliquot of $5 \mu \mathrm{L}$ of each nested-PCR product was subjected to digestion with $R s a$ I restriction enzyme (Amersham Biosciences), for $12 \mathrm{hs}$ at $37^{\circ} \mathrm{C}$, according to manufacturer's protocol. Restriction products were separated through electrophoresis on a $3.0 \%$ agarose gel, visualized by staining with ethidium bromide, followed by ultraviolet transillumination, and then digitalized (Digital Kodak Science $\left.1 \mathrm{D}^{\mathrm{TM}}\right)$. Size markers included in all gels were $100 \mathrm{bp}$ DNA Ladder (Invitrogen, Brazil). The RFLP patterns of different Cryptosporidium isolates were compared to the sequences available in the GenBank.

\section{RESULTS}

Amplicons with the expected size were generated from 14 isolates using the COWP Nested-PCR. In order to characterize these amplicons, we used a standard RFLP protocol with $R s a$ I restriction enzyme. Three distinct RFLP patterns were obtained, which indicated the presence of $C$. parvum, C. hominis, and C. meleagridis based on patterns that could be obtained with COWP gene sequences for these three species available in GenBank. Eight isolates revealed fragments of 284, 129, 106 and 34-bp which would indicate the presence of $C$. hominis, based on RsaI RFLP patterns with GenBAnk accession numbers: AF248741; AJ849458; AJ849459; AY282691; AJ971799; AJ971800 and AJ971801. Fragments of 413, 106 and 34-bp were obtained from four samples, and these were related to $C$. parvum based on the same rationale using GenBank accession numbers: AB89292; AF248743; AF266265; AF266273; AY277701; and Z22537. Fragments of 372, 147 and 34-bp were obtained from two samples, which would indicate the presence of $C$. meleagridis, based on GenBank accession numbers: AF248742; AF266266; AJ971802; AY166840; AY282694 and DQ116568. The distribution of the 14 Cryptosporidium isolates according to the identified species and the city of origin, Taubaté (TT), Sorocaba (SO) and São Paulo (SP), was presented in the Table 1. Representation of the sites of cleavage (GT $\downarrow$ AC) found in the Cry15/Cry9 amplicons is showed in Fig. 1. A representative gel showing RFLP profiles of three genetic groups, detected in this study, is shown in Fig. 2.

\section{DISCUSSION}

The relevance of Cryptosporidium sp. as a causative agent of severe and chronic diarrhea, representing an important cause of morbidity and mortality among malnourished children and immunocompromised patients, such as those infected with HIV or submitted to organ transplants ${ }^{8,25,28}$, has been extensively discussed in the literature. However, the prevalence of this parasite in immunocompetent children is not well known. The morphologic diagnosis of this parasite is a challenge for microscopist unless they are very well trained in recognizing Cryptosporidium sp. oocysts in stool samples. This is enhanced by the fact that not all clinical laboratories in Brazil perform special staining techniques, eg, modified acid-fast recommended for 


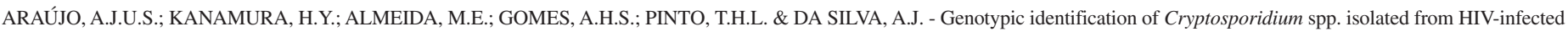
patients and immunocompetent children of São Paulo, Brazil. Rev. Inst. Med. trop. S. Paulo, 50(3): 139-143, 2008.

Table 1

Cryptosporidium isolates according to the identified species and the city of source for stool samples

\begin{tabular}{|c|c|c|c|c|}
\hline \multirow{2}{*}{$\begin{array}{l}\text { City of source for } \\
\text { stool samples }\end{array}$} & \multicolumn{3}{|c|}{ Cryptosporidium species } & \multirow{2}{*}{$\begin{array}{c}\text { Total number } \\
\text { of isolates }\end{array}$} \\
\hline & C. hominis & C. parvum & C. meleagridis & \\
\hline Sorocaba & $2^{\text {(a) }}$ & $1^{\text {(b) }}$ & $2^{(\mathrm{c})}$ & 5 \\
\hline São Paulo & $4^{(\mathrm{d})}$ & $1^{\text {(e) }}$ & - & 5 \\
\hline Taubaté & $2^{(\mathrm{f})}$ & $2^{(g)}$ & - & 4 \\
\hline Total & 8 & 4 & 2 & 14 \\
\hline
\end{tabular}

(a) samples SO322, SO507; (b) sample SO49; ${ }^{\left({ }^{(c)}\right.}$ samples SO623 and SO689; ${ }^{(\mathrm{d})}$ samples SP06, SP07, SP17, SP31; ${ }^{(\mathrm{e})}$ sample SP12; ${ }^{\left({ }^{(\mathrm{f})}\right.}$ samples TT03 and TT06; ${ }^{(\mathrm{g})}$ samples TT01 and TT07.
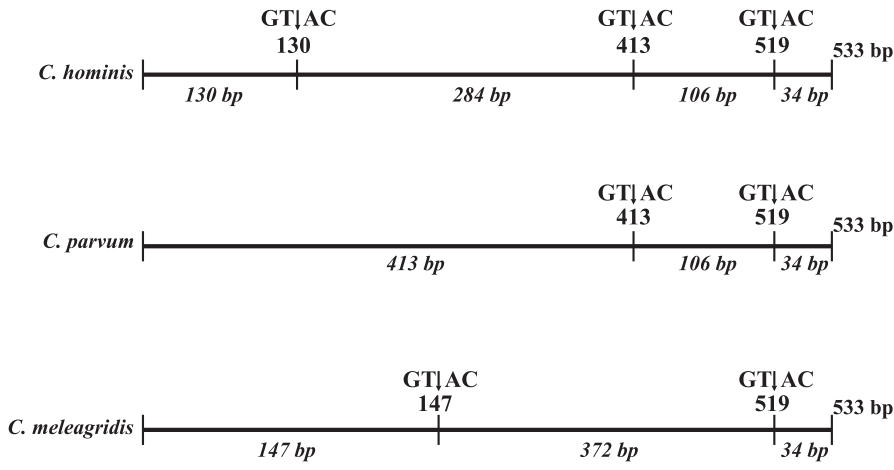

Fig. 1 - Representation of the fragments produced by digestion with RsaI on COWP gene, generated after nested PCR with primers Cry15/Cry9, from C. hominis, C. parvum, and C. meleagridis. The numbers above the line represent the nucleotide positions where Rsa cleavage sites are located, and the numbers below represent the size of the restriction fragments produced in each species.

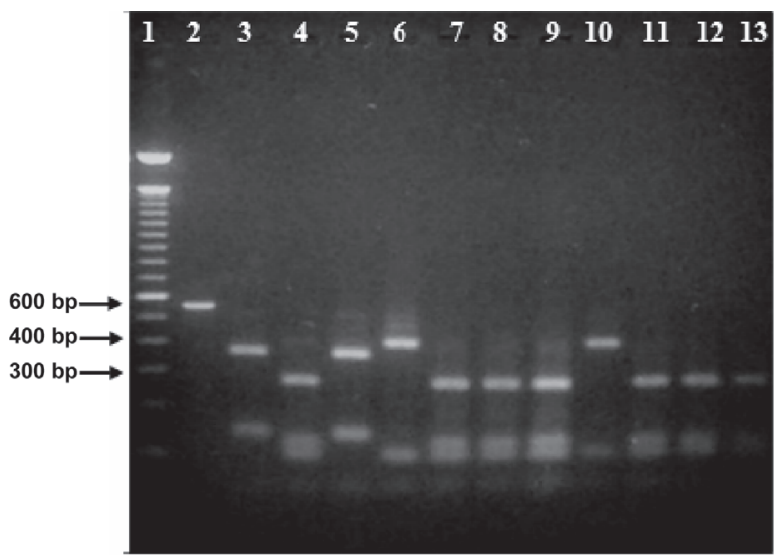

Fig. 2 - Restriction patterns of the COWP gene nested-PCR products of $553 \mathrm{bp}$, amplified with the primers Cry15/Cry9, from two Cryptosporidium isolates from Taubate (TT), four from Sorocaba (SO), and five from Sao Paulo (SP). 100-bp Ladder DNA (lane 1); undigested Cry15-Cry9 amplicon (lane 2); C. meleagridis: SO689 (lane 3), SO623 (lane 5); C. hominis: SP31 (lane 4), TT03 (lane 7), SP06 (lane 8), SP07 (lane 9), SO322 (lane 11), SP17 (lane 12), and SO507 (lane 13); C. parvum: TT07 (lane 6) and SP12 (lane 10).

the detection of Cryptosporidium sp. oocysts ${ }^{16}$. Also, in Brazil, it is not a practice among the pediatricians to request a specific laboratory diagnostic test for cryptosporidiosis in cases of diarrhea illness.
Among the 16 currently accepted species of Cryptosporidium ${ }^{27}, C$. hominis and $C$. parvum are the most frequently associated to human infections. However, zoonotic species, such as C. meleagridis, C. felis, and $C$. canis, and also other genotypes of $C$. parvum, adapted to varied animal species, have been isolated from patients with cryptosporidiosis and identified by molecular methods ${ }^{18,21,22,24,29,30}$. These findings bring up evidences that different species of Cryptosporidium can circulate in the environment, being potential pathogens for humans and animals; this justify the use of molecular techniques for characterization of Cryptosporidium at species level, for better understanding the epidemiology of cryptosporidiosis in specific areas.

The occurrence of the Cryptosporidium anthroponotic and the zoonotic transmission cycles overlapping in the same area enhances the exposure of human beings to this parasite, especially in areas with inadequate sanitary infrastructure. Consequently, contaminated water and foods can be important vehicles for transmission of cryptosporidiosis $^{12}$. For obvious reasons, special attention must be given to water, considering that Cryptosporidium oocysts are resistant to chlorination. Thus, efforts to improve detection and identification of the parasite as well as disinfection of drinking and recreational water have been the focus of many public health programs worldwide. Nowadays it is important that the diagnosis of cryptosporidiosis must be carried out not only by morphologic criteria, but also by molecular techniques to allow accurate identification of Cryptosporidium at species level. Several species of this genus are morphologically indistinguishable and only microscopic examination is not enough for species identification in clinical or environment samples.

In the present study, the use of molecular tools allowed the identification of three different species of Cryptosporidium, i.e., C. hominis, $C$. parvum and $C$. meleagridis, the later being identified only in two HIV-infected patients. It is known that this species naturally infect different species of birds, and in humans it is more frequently described in HIV-infected patients, although different authors have identified cases of C. meleagridis infection not restricted to immunocompromised individuals ${ }^{6,22,29}$. Among the nine immunocompetent children studied, six cases were associated with infection by $C$. hominis and three cases by $C$. parvum. Although the number of samples studied was not large, the observation that more infections with $C$. hominis than $C$. parvum were detected may indicate the predominance of the anthroponotic cycle in the studied areas. This situation was more evident among the children living in a slum of the São Paulo City, where four samples were positive for $C$. hominis and 


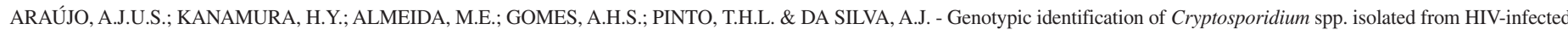
patients and immunocompetent children of São Paulo, Brazil. Rev. Inst. Med. trop. S. Paulo, 50(3): 139-143, 2008.

only one was positive for $C$. parvum. It is also interesting to notice the identification of two cases of $C$. parvum and two of $C$. hominis among the day care children in Taubaté City. It can suggest a possible occurrence of person-to-person transmission of some zoonotic species, after its introduction into confined environments, such as day-carecenters, home-care and hospital settings; and then, it might be able to present an anthroponotic standard of transmission, with a significant epidemiological implication on public health. The use of molecular tools in studies such as the one presented here will allow better characterization of Cryptosporidium species, which is helpful to identify the source of infections and risk factors, and to allow the control of cryptosporidiosis in our communities.

\section{RESUMO}

\section{Identificação genotípica de Cryptosporidium spp. isolados a partir de pacientes com HIV e crianças imunocompetentes de São Paulo, Brasil}

Isolados de Cryptosporidium identificados em quatorze amostras de fezes, coletadas de cinco pacientes com infecção por HIV e de nove crianças imunocompetentes, residentes no estado de São Paulo, Brasil, foram submetidos a análise molecular por Nested-PCR, seguido da caracterização genética por polimorfismo do tamanho do fragmento de restrição (RFLP). A análise foi baseada na digestão, com a enzima de restrição $R s a \mathrm{I}$, de um fragmento de DNA amplificado do gene que codifica a proteína de parede do oocisto de Cryptosporidium (COWP). Baseado nesta análise, quando comparado aos padrões utilizados, quatro amostras foram identificadas como Cryptosporidium parvum, oito como Cryptosporidium hominis e duas apresentaram um perfil correspondente ao de Cryptosporidium meleagridis. O uso de métodos moleculares pode ser útil para identificar a fonte das infecções e os fatores de risco relacionados à infecção por Cryptosporidium em nossas comunidades.

\section{ACKNOWLEDGEMENTS}

To FAPESP - Fundação de Amparo à Pesquisa do Estado de São Paulo - for the financial support (Proc. 00/13985-5).

\section{REFERENCES}

1. AGNEW, D.G.; LIMA, A.A.; NEWMAN, R.D. et al. - Cryptosporidiosis in northeastern Brazilian children: association with increases diarrhea morbidity. J. infect. Dis., 177: 754-760, 1998

2. BRANTLEY, R.K.; WILLIAMS, K.R.; SILVA, T.M.J. et al. - AIDS-associated diarrhoea and wasting in northeast Brazil is associated with subtherapeutic plasma levels of antiretroviral medications and with both bovine and human subtypes of Cryptosporidium parvum. Braz. J. infect. Dis., 7: 16-22, 2003.

3. BRASIL. Ministério da Saúde. Secretaria de Vigilância em Saúde. Coordenação-Geral de Vigilância em Saúde Ambiental - Portaria MS nº 518/2004. Brasília. Série E. Legislação de Saúde, 2004.

4. CAMA, V.A.; BERN, C.; SULAIMAN, I.M. et al. - Cryptosporidium species and genotypes in HIV-positive patients in Lima, Peru. J. eukaryot. Microbiol., 50 (suppl.): 531-533, 2003.

5. CARVALHO-ALMEIDA, T.T.; PINTO, P.L.S.; QUADROS, C.M.S. et al. - Detection of Cryptosporidium sp. in non diarrheal faeces from children, in a day care center in the city of São Paulo, Brazil. Rev. Inst. Med. trop. S. Paulo, 48: 27-32, 2006.
6. CHALMERS, R.M.; ELWIN, K.; THOMAS, A.L. \& JOYNSON, D.H. - Infection with unusual types of Cryptosporidium is not restricted to immunocompromised patients. J. infect. Dis., 185: 270-271, 2002.

7. CHIEFFI, P.P.; PASCHOALOTTI, M.A.; VERGUEIRO, C.S. \& CHIATTONE, C.S. Infection by Cryptosporidium sp. in immunocompromised haematological patients. Rev. Inst. Med. trop. S. Paulo, 47: 301-302, 2005.

8. CIMERMAN, S.; CIMERMAN, B. \& LEWI, D.S. - Prevalence of intestinal parasitic infections in patients with acquired immunodeficiency syndrome in Brazil. Int. J. infect. Dis., 3: 203-206, 1999.

9. COX, M.J.; ELWIN, K.; MASSAD, E. \& AZEVEDO, R.S. - Age-specific seroprevalence to an immunodominant Cryptosporidium sporozoite antigen in a Brazilian population. Epidem. Infect., 133: 951-956, 2005.

10. DA SILVA, A.J.; BORNAY-LLINARES, F.J.; MOURA, I.N.S. et al. - Fast and reliable extraction of protozoan parasite DNA from fecal specimens. Mol. Diagn., 4: 57-64, 1999.

11. FARIAS, E.W.C.; GAMBA, R.C. \& PELLIZARI, V.H. - Detection of Cryptosporidium spp. oocysts in raw sewage and creek water in the city of Sao Paulo, Brazil. Braz. J. Microbiol., 33: 41-43, 2002.

12. FAYER, R.; MORGAN, U. \& UPTON, S.J. - Epidemiology of Cryptosporidium: transmission, detection and identification. Int. J. Parasit., 30: 1305-1322, 2000.

13. FRANCO, R.M.B.; ROCHA-EBERHARDT, R. \& CANTUSIO NETO, R. - Occurrence of Cryptosporidium oocysts and Giardia cysts in raw water from the Atibaia river, Campinas, Brazil. Rev. Inst. Med. trop. S. Paulo, 43: 109-111, 2001.

14. GATEI, W.; GREENSILL, J.; ASHFORD, R.W. et al. - Molecular analysis of the $18 \mathrm{~S}$ rRNA gene of Cryptosporidium parasites from patients with or without humam immunodeficiency virus infections living in Kenya, Malawi, Brazil, the United Kingdom, and Vietnam. J. clin. Microbiol., 41: 1458-1462, 2003.

15. GONÇALVES, E.M.N.; DA SILVA, A.J.; EDUARDO, M.B.P. et al. - Multilocus genotyping of Cryptosporidium hominis associated with diarrhea outbreak in a day care unit in São Paulo. Clinics, 61: 119-126, 2006.

16. JONES, J.L.; LOPEZ, A.; WAHLQUIST, S.P. et al. - Survey of clinical laboratory practices for parasitic diseases. Clin. infect. Dis., 38(suppl 3): S198-S202, 2004.

17. MacKENZIE, W.R.; HOXIE, N.J.; PROCTOR, M.E. et al. - A massive outbreak in Milwaukee of Cryptosporidium infection transmitted through the public water supply. New Engl. J. Med., 331: 161-167, 1994

18. MATOS, O.; ALVES, M.; XIAO, L.; CAMA, V. \& ANTUNES, F. - Cryptosporidium felis and C. meleagridis in persons with HIV, Portugal. Emerg. infect. Dis., 10: 2256-2257, 2004.

19. MEDEIROS, M.I.C.; NEME, S.N.; DA SILVA, P. et al. - Etiology of acute diarrhea among children in Ribeirão Preto - SP, Brasil. Rev. Inst. Med. trop. S. Paulo, 43: 21-24, 2001.

20. MONIS, P.T. \& THOMPSON, R.C.A. - Cryptosporidium and Giardia zoonoses: fact or fiction? Infect. Genet. Evolut., 3: 233-244, 2003.

21. MUTHUSAMY, D.D.; RAO, S.S.; RAMANI, S. et al. - Multilocus genotyping of Cryptosporidium $\mathrm{sp}$. isolates from human immunodeficiency virus-infected individuals in South India. J. clin. Microbiol., 44: 632-634, 2006.

22. PEDRAZA-DÍAZ, S.; AMAR, C.F.; McLAUCHLIN, J. et al. - Cryptosporidium meleagridis from humans: molecular analysis and description of affected patients. J. Infect., 42: 243-250, 2001

23. PEDRAZA-DIAZ, S.; AMAR, C.; NICHOLS, G.L. \& McLAUCHLIN, J. - Nested polymerase chain reaction for amplification of the Cryptosporidium oocyst wall protein gene. Emerg. infect. Dis., 7: 49-56, 2001. 
ARAÚJO, A.J.U.S.; KANAMURA, H.Y.; ALMEIDA, M.E.; GOMES, A.H.S.; PINTO, T.H.L. \& DA SILVA, A.J. - Genotypic identification of Cryptosporidium spp. isolated from HIV-infected patients and immunocompetent children of São Paulo, Brazil. Rev. Inst. Med. trop. S. Paulo, 50(3): 139-143, 2008.

24. PIENIAZEK, N.J.; BORNAY-LLINARES, F.J.; SLEMENDA, S.B. et al. - New Cryptosporidium genotypes in HIV-infected persons. Emerg. infect. Dis., 5: 444 449, 1999.

25. SAREDI, N. \& BAVA, J. - Cryptosporidiosis in pediatric patients. Rev. Inst. Med. trop. S. Paulo, 40: 197-200, 1998 .

26. SPANO, F.; PUTIGNANI, L.; McLAUCHLIN, J.; CASEMORE, D.P. \& CRISANTI, A. - PCR-RFLP analysis of the Cryptosporidium oocyst wall protein (COWP) gene discriminates between $C$. wrairi and $C$. parvum, and between $C$. parvum isolates of human and animal origin. FEMS Microbiol. Lett., 150: 209-217, 1997.

27. SUNNOTEL, O.; LOWERY, C.J.; MOORE J.E. et al. - Cryptosporidium. Lett. appl. Microbiol., 43: 7-16, 2006.
28. TZIPORI, S. \& WARD, H. - Cryptosporidiosis: biology, pathogenesis and disease. Microbes Infect., 4: 1047-1058, 2002.

29. XIAO, L.; BERN, C.; LIMOR, J. et al. - Identification of 5 types of Cryptosporidium parasites in children in Lima, Peru. J. infect. Dis., 183: 492-497, 2001.

30. XIAO, L. \& RYAN, U.M. - Cryptosporidiosis: an update in molecular epidemiology Curr. Opin. infect. Dis., 17: 483-490, 2004.

Received: 28 September 2007

Accepted: 21 February 2008 